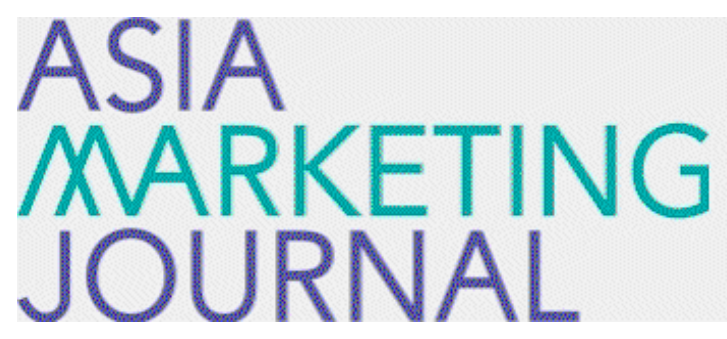

ASIA MARKETING JOURNAL

Volume 7 | Issue 1

Article 5

4-27-2005

\title{
LG생활건강 백화점 화장품 브랜드 오휘의 CRM전략
}

Wan Soo Lee

Won Moo Hur

Follow this and additional works at: https://amj.kma.re.kr/journal

Part of the Marketing Commons

\section{Recommended Citation}

Lee, Wan Soo and Hur, Won Moo (2005) "LG생활건강 백화점 화장품 브랜드 오휘의 CRM전략," Asia Marketing Journal: Vol. 7 : Iss. 1 , Article 5.

Available at: https://doi.org/10.53728/2765-6500.1139

This Article is brought to you for free and open access by Asia Marketing Journal. It has been accepted for inclusion in Asia Marketing Journal by an authorized editor of Asia Marketing Journal. 


\title{
LG생활건강 백화점 화장품 브랜드 오휘의 CRM전략
}

\section{LG Household and Healthcare' Cosmetic Brand, OHUI CRM Strategy Case}

\author{
이 완 수(Lee, Wansoo)* \\ 허 원 무(Hur, Wonmoo) ${ }^{* *}$
}

백화점 화장품 채널에서 중간 순위에 위치한 LG생활건강 오휘 브랜드는 자사의 약한 브랜드 파워 률 고객관계전략을 통해 상쇄함으로써 고객충성도 및 매출, 시장점유율 등의 시장성과를 제고시킬 수 있었다. 오휘는 자사의 $\mathrm{CRM}$ 활동에 대한 체계적인 리뷰를 통해 문제점을 파악하고, 이를 개선하기 위한 구체적인 전략들을 선정하였다. 선두 기업이 되기 위한 기반인 Critical Mass의 고객을 확보하 고, 맞춤형 충성도 프로그램을 개발하여 고객충성도를 증가시켰다. 또한 전략의 실행력을 높이기 위 해서 현장의 직원들이 실제 고객들을 판별해서 편익 프로그램을 구현할 수 있도록 고객 등급을 단순 화시켰다. 마지막으로 $\mathrm{CRM}$ 활동이 전사적으로 자리 잡을 수 있도록 성공사례 공유를 통한 지식 화 산과 더불어 성과보상 체계(KPI)를 $\mathrm{CRM}$ 에 연결시켰다. 이러한 일련의 활동을 통해 오휘 브랜드는 시장점유율의 상승 및 경쟁사보다 높은 매출 성장률, 고객만족도 제고를 이루었다.

핵심개념: 브랜드 오휘, $\mathrm{CRM}$, 고객관계전랴, $\mathrm{KPI}$

\section{I. 서 론}

최근 국내 고급 화장품 시장은 태평양, $\mathrm{LG}$ 생 활건강 ${ }^{1)}$ 등 국내 브랜드와 샤넬, 크리스천 디 올, 에스티 로더 등의 글로벌 브랜드들이 치열 하게 경쟁하고 있는 상황이다. 국내 브랜드는
글로벌 브랜드에 비해서 브랜드 파워가 상대적 으로 약하기 때문에 유통점포와 방문판매 확장 같은 유통망에 집중한 마케팅에 치중해왔다. 그 러나 많은 백화점들이 자사 브랜드 이미지 및 매출을 제고시키기 위해 국내 브랜드들을 퇴출 시키거나 점포의 위치를 소비자들이 찾기 어려 운 곳으로 이동시키는 상황이 빈번하게 나타나

* 연세대학교 경영학과 교수(wslee@base.yonsei.ac.kr)

** LG경제연구원 선임연구원, 연세대학교 경영학과 박사과정(wmhur@hanmail.net)

1) 사례개발에 도움을 주신 $\mathrm{LG}$ 생활건강 관계자분들께 사의를 표합니다. 
면서 유통망 집중 전략도 점차 어려워지고 있 는 상황이다.

한편, 국산 고가 화장품 브랜드들은 기능이나 제품 품질은 우수하나 브랜드가 창출하는 이미 지나 개성이 외국 브랜드에 비해 뒤쳐져 있다 고 판단하고 브랜드 육성에 집중적인 투자를 해왔다. 그러나 이러한 투자에도 불구하고 태평 양의 헤라를 제외한 국산 고가 브랜드들은 강 력한 브랜드 파워를 구축하지 못하고 있는 상 황이다.

이러한 상황에서 브랜드 파워 및 자산 제고를 위해 지속적으로 마케팅 자원과 역량을 집중하 는 것은 마케팅 효율성 측면에서 생각해볼 문 제이다. 즉, 소비자들이 화장품을 통해 얻으려 고 하는 편익이나 가치를 다른 방법으로 채워 줄 수 있는 전략을 모색할 필요가 있다. 이는 화장품산업에만 국한되는 문제는 아니다. 비록 브랜드 자산이 사업의 핵심역량으로 중요하지 만, 현실적으로 이를 확보하지 못한 기업들에게 는 강력한 브랜드 파워를 대체할 수 있는 마케 팅 전략이 필요하다. 특하 특정 산업이나 사업 의 후위 기업들이 빈번하계 경험하게 되는 현 실적인 문제이다. 후위 기업들은 1,2 위 기업들 에 비해 매출뿐만 아니라 수익성(영업이익)이 상당히 떨어진다. 이 상태에서 브랜드에 대한 대규모 투자를 하는 것은 수익성을 악화시키는 악순환을 반복하게 만드는 원인이 된다. 이에 $\mathrm{GE}$ 나 유니레버 등 세계 유수의 기업들은 1,2 위 사업이나 브랜드를 중심으로 사업을 영위하고 있다(Welch 2001: Kumer 2004).

이에 대한 대안으로 고객별로 차별적인 편익 을 제공하는 고객관계관리(이하에서는 $\mathrm{CRM}$ 이 라고 한다) 마케팅전략을 생각해 볼 수 있다.
브랜드 마케팅은 기업이 보유하고 있는 브랜드 자산(인지도, 이미지, 영향력 등)을 적극적으로 활용해서 수익성을 제고하는 전략으로, 강력한 브랜드 파워가 전제되어야 한다. 이에 비해 $\mathrm{CRM}$ 은 목표 고객에게 맞춤 편익과 차별화된 정보 등을 제공함으로써 고객만족도와 충성도 를 높여 장기적인 수익성을 제고시키는 전랴으 로 체계적인 비즈니스 시스템과 종업원 교육훈 련이 중요하다. 한편, 브랜드 마케팅과 $\mathrm{CRM}$ 은 상호 독립적이지 않고 서로 영항을 줌으로써 시너지를 창출한다. 강력한 브랜드를 가지고 있 을 경우에는 $\mathrm{CRM}$ 의 첫 단계인 신규고객확보 가 용이하며. 강력한 $\mathrm{CRM}$ 활동은 고객만족도 제고 및 긍정적인 구전을 발생시켜 브랜드 자 산 제고에 기여한다(박성연 2003).

한편, 화장품사업처럼 전통적으로 브랜드가 중요한 $\mathrm{KSF}$ (key success factor; 핵심성공요 인)이지만, 이를 현실적으로 제고하기 어려운 상황에서 $\mathrm{CRM}$ 전략으로 성공한 사례가 $\mathrm{LG}$ 생 활건강의 오휘 브랜드다. LG생활건강의 오휘 브랜드는 시장에서 태평양 헤라 브랜드와 글로 벌 브랜드들에 밀려 중간 수준의 브랜드 파워 와 매출을 기록하고 있다. 그러나 최근 오휘는 체계적으로 고객관계관리전략을 수립하고 이를 효과적으로 실행하여 사업성과를 개선시키고 있다. 즉. 브랜드 파워가 약한 후위 브랜드의 전략적 대안으로서 $\mathrm{CRM}$ 의 가능성을 보여주고 있다.

오휘 사례 분석을 통해 고객 수가 절대적으로 부족하고, 브랜드 파워와 매장이 열세인 상황에 서 체계적인 고객관계관리가 어떻게 기업 성과 를 제고시켰는지를 보여줌으로써 마케팅 관리 상의 여러 시사점을 제공해 주려고 한다. 즉, 
LG생활건강의 대표적 고급 화장품 브랜드인 오휘가 매출 개선과 핵심 경쟁력 강화를 이루 기 위해 어떻게 Critical Mass의 고객을 확보하 고. 이들을 충성고객으로 전환시키기 위해 어 떠한 방식으로 차별적인 편익을 제공했는지를 알아보려고 한다. 그리고 이러한 접근 방법들 이 후위 기업이나 브랜드들의 마케팅 전략에 어떠한 시사점을 줄 수 있을지를 살펴보려고 한다.

또한 이 사례는 기존 국내 기업들에게 혁신 과 변화전략 측면에서 여러 시사점을 제공해 주고 있다. 많은 기업들이 초기에 체계적인 전 략 없이 $\mathrm{CRM}$ 을 도입하였다. 그러나 운영 성 과가 예상보다 낮게 나타나자. 이에 대한 개선 보다는 회의를 가진 경우가 빈번했다. 그러나 $\mathrm{CRM}$ 은 살아있는 유기체와 같이 지속적인 혁 신과 업데이트가 필요하며, 변화를 주지 않으 면 성공할 수 없다는 것을 이 사례는 시사해 주고 있다.

\section{II. 화장품 시장 및 $\mathrm{LG}$ 생활건강 분석}

\section{1 화장품 시장의 특성과 현황}

2003년 기준 국내 화장품 시장 규모는 약 6 조 1400 억 원이며, 2000 2003년까지 연평균 $13.2 \%$ 의 고성장을 하고 있다. 그 중에서 국내 백화점 에서 판매된 60 개 화장품 브랜드 매출은 약 1 조 72 억 원으로 약 $16.5 \%$ 를 차지하고 있다(장 업신문 2004).

국내 화장품 시장은 1990년대 초반까지 태평 양과 LG생활건강이 시장을 양분해 왔다. 그러 나 1990년대 중반 이후 고가 외국 브랜드들이 국내에 진출하면서 백화점 채널을 중심으로 시 장을 급속히 확장하고 있는 상황이다(<그림 2-1) 참고).

화장품 시장은 판매되는 채널에 따라 백화점. 전문점, 슈퍼마켓과 할인마트, 방문판매 시장으

〈그림 2-1〉 국내 화장품 시장 규모 및 시장점유율
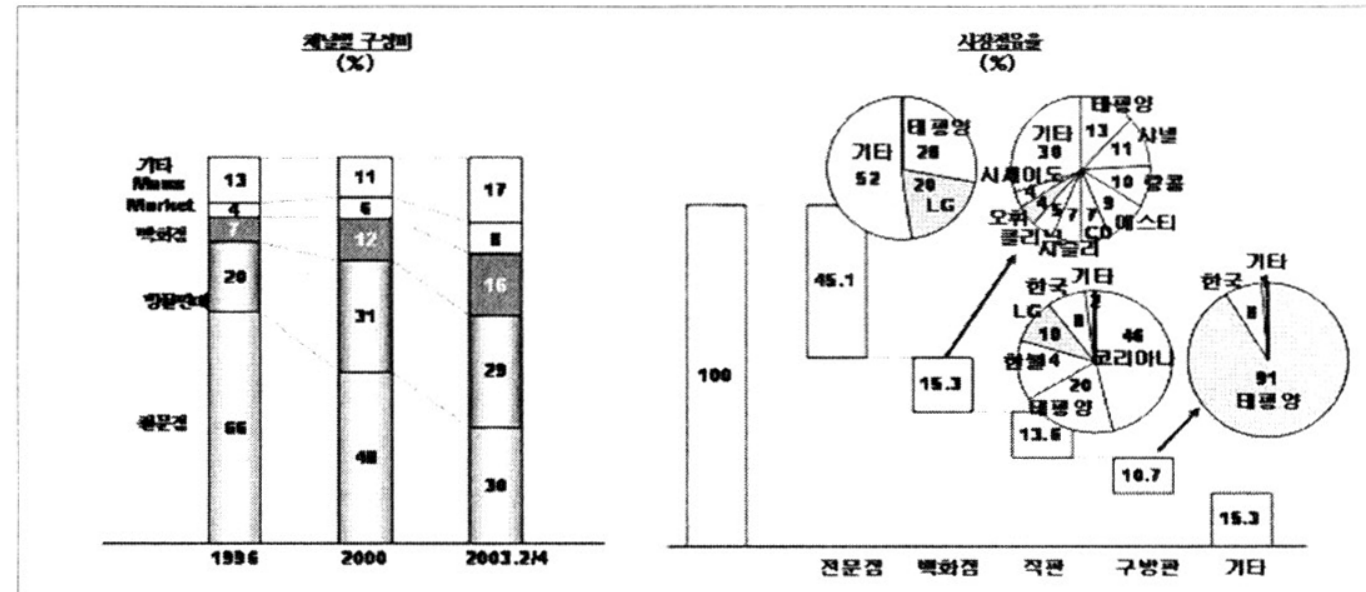
로 나누어진다. 최근의 시장은 백화점, 방문판 매 시장의 규모는 커지고 있는 반면, 전통적인 매스마켓인 전문점 시장은 점차 줄어들고 있는 상황이다(장업신문 2003).

국내 시장에서 업계 1 위를 차지하고 있는 회 사는 태평양으로, 백화점 채널에서는 헤라와 설 화수라는 브랜드를 보유하고 있다. 두 브랜드는 모두 천억 원 이상의 매출을 기록하고 있다. 태 평양은 전 채널에서 고루 강세를 보이고 있으 나. 특히 백화점과 방문판매 시장에서 강력한 경쟁력을 확보하고 있다. 2003년 기준 약 $30 \%$ 의 시장점유율을 차지하고 있다(한국경제 2003).

경쟁사인 $\mathrm{LG}$ 생활건강은 시장이 점차 축소되 어가는 전문점 시장(이자녹스, 라끄베르 등의 브랜드를 보유)에서 경쟁우위를 보이고 있다. 한편, 최근 급성장하는 고가 시장을 차지하기 위해 오휘, 노블라임 등의 브랜드를 백화점에 출시해서 운영하고 있으며, 시장점유율 약 $18 \%$ (2003년 기준)을 차지하고 있다(파이넨설뉴스 2003).

이외에 외국 브랜드인 샤넬, 에스티 로더. 크 리스천 디올, 시세이도 등이 유명 백화점에 속 속 입점하고 있으며, 매장 수와 면적을 넓혀가 고 있다. 또한 강력한 브랜드 파워와 적극적인 마케팅 투자로 고소득층과 젊은 여성을 중심으 로 고객을 확대하고 있다. 외국 브랜드들의 공 격적인 투자와 시장 확대에 따라 외국 브랜드 의 시장점유율은 2002년 말 약 $23 \%$ 에서 2005 년 $30 \%$ 까지 확대될 것으로 업계전문가들은 추 정하고 있다(한국경제 2003). 이에 비해 국내 중소 브랜드들은 유명 백화점에서 점차 퇴출되 고 있다. 또한 매장 면적이 축소되거나. 매장 위치가 나빠지는 어려움에 처해있다.

\section{$2.2 \mathrm{LG}$ 생활건강 및 오휘 브랜드 소개}

LG생활건강은 1947년 화장품사업에 첫발을 내디뎠으며 현재 치약, 비누 등 가정생할용품과 이자녹스, 라끄베르, 오휘 등의 화장품을 생산 판매하고 있다(2004 LG생활건강). 2003년 기준 약 1 조원의 매출을 기록하고 있고, 약 2,700명 의 임직원을 고용하고 있다. LG생할건강은 생 활용품 사업부와 화장품 사업부의 두 개 사업 부를 가지고 있으며, 현재 생활용품 부문에서는 국내 시장 1 위, 화장품 부문에서는 태평양 다음 의 2 위를 차지하고 있다(화장품부문 순위는 백 화점, 전문점, 할인점 판매를 포함한 총 매출을 기준).

한편, LG생할건강은 화장품에 대한 수십 년 이상의 노하우를 바탕으로 1997년 샤넬, 랑콤 등 외국 브랜드들이 주도하고 있던 백화점 화 장품 매장에 "피부가 느끼는 아름다움의 차이" 라는 슬로건을 내걸고 프리미엄 화장품 오휘를 출시하게 되었다. 오휘는 기존의 국산 제품과 차별화되고 고급스러움을 강조한 브랜드로 백 화점 채널을 통해 판매되고 있다(오휘 2004). 오휘 브랜드는 2003 년 기준 약 470 억 원의 매 출을 기록, 백화점 채널에서 약 $4.7 \%$ 의 시장점 유율을 차지하고 있다(장업신문 2004; 파이넨 설뉴스 2003).

오휘는 2002년 기준, 백화점채널 브랜드 매출 9위를 차지하고 있다. 그러나 점당 매출액은 15 위로 마케팅 효율성 측면에서 문제가 있는 것 으로 나타나고 있다(장업신문 2003). 게다가 자 사 및 관련 업계에서 실시한 브랜드 성과 조사 에서도 경쟁사에 비해 열세로 나타나고 있다 (CMN 2003). 브랜드 출시 후 브랜드 매력도를 
〈그림 2-2〉 각사의 강점과 약점 비교 및 전략적 방향

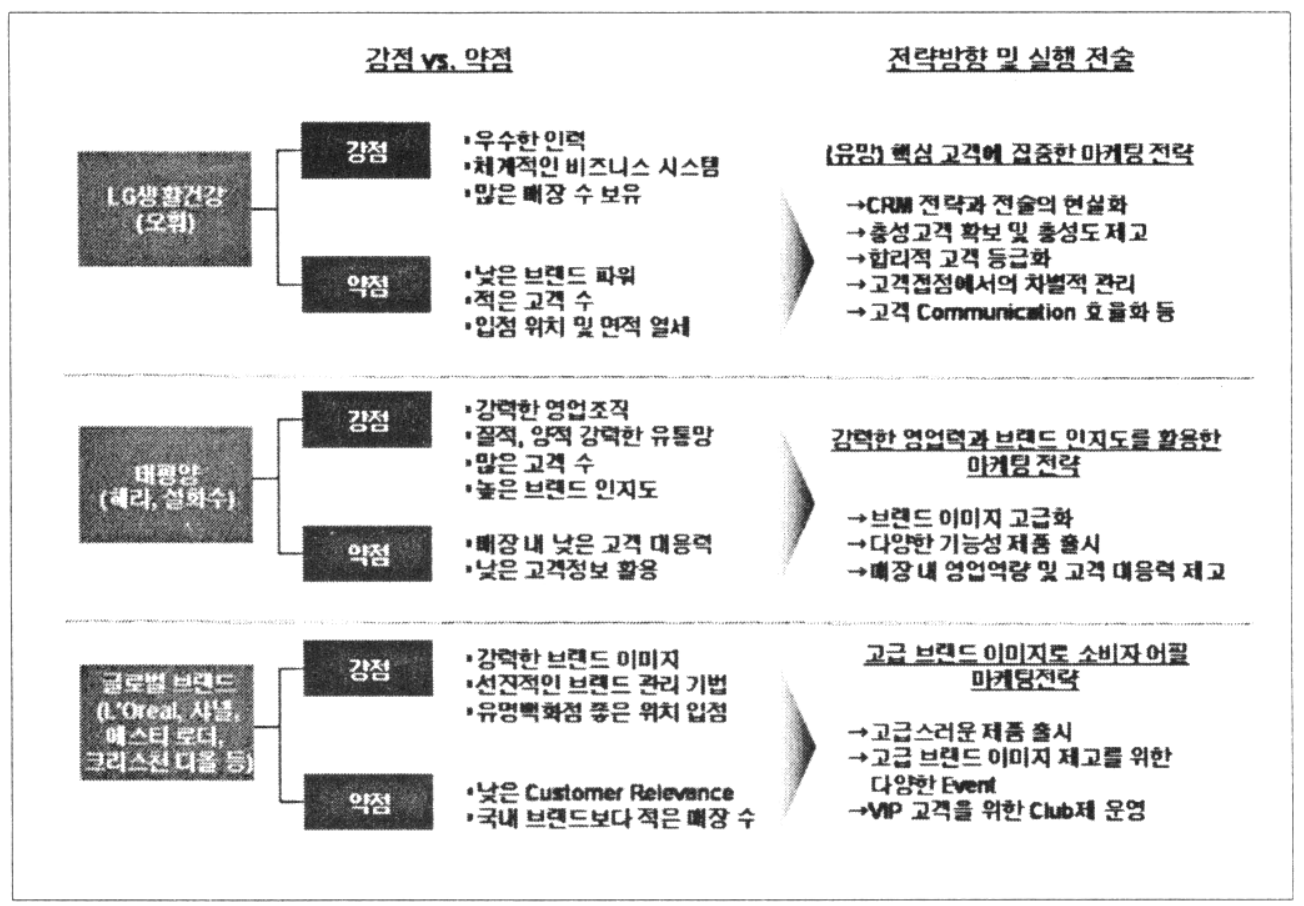

〈표 2-1〉2002년 주요 화장품 브랜드 매출 현황

\begin{tabular}{|c|c|c|c|}
\hline 순위 & 브랜드 & 전체 매출액(억원) & 점당 매출액(억원) \\
\hline 1 & 헤라\& 설화수 & 1,117 & 20.5 \\
\hline 2 & 에스티 로더 & 904 & 20.1 \\
\hline 3 & 랑콤 & 900 & 18.4 \\
\hline 4 & 샤넬 & 890 & 18.1 \\
\hline 5 & 크리스천 디올 & 610 & 12.2 \\
\hline 6 & 시슬리 & 570 & 20.4 \\
\hline 7 & 크리니크 & 453 & 11.3 \\
\hline 8 & 사세이도 & 400 & 9.1 \\
\hline 9 & 오화 & 398 & 7.0 \\
\hline 10 & 비오템 & 316 & 9.6 \\
\hline 11 & 아베다 & 212 & 11.8 \\
\hline 12 & 겔랑 & 198 & 7.3 \\
\hline 13 & 바비브라운 & 186 & 12.4 \\
\hline 14 & 라프레리 & 159 & 9.4 \\
\hline 15 & 맥 & 151 & 13.7 \\
\hline
\end{tabular}

자료: 장업신문(2003. 10) 
높이기 위해 잡지 등의 매체를 통해 브랜드 광 고를 하였으나, 외국 브랜드는 물론, 태평양의 설화수나 헤라에 비해서도 브랜드 이미지와 개 성이 약했다. 이 상황에서 오휘 브랜드 관계자 들은 제한된 마케팅 자원을 브랜드 부문에 투 자하기보다 효율성 높은 새로운 마케팅 전략을 모색하게 되었다. 즉, 오휘의 역량을 고려할 때, 수익성 높은 우량고객을 발굴하고 그들에게 차 별화된 편익을 제공하는 것이 바람직하다는 판 단을 하게 되었다. 이에 따라 오휘는 $\mathrm{CRM}$ 으로 눈을 돌리게 되었다(〈그림 2-2〉 참고).

\section{III. 백화점에서 $\mathrm{CRM}$ 의 의미}

\section{$3.1 \mathrm{CRM}$ 의 정의와 출현 배경}

$\mathrm{CRM}$ 이란 기업의 기존 및 잠재고객의 욕구 를 이해하고 예측하고 관리하는데 중점을 둔 기업전량이며, 고객 주변의 기업 활동을 효율 적으로 관리하기 위해 추구하는 전략적, 조직 적. 기술적 변화 프로세스이다. 또한 고객 정보 의 흭득과 전랴적 배치, 그리고 다양한 고객 접점에서 적절한 운용을 통해 고객만족도를 극 대화하고 그에 상응하는 수익과 이윤을 창출하 는 과정을 의미한다(Brown 2001). CRM은 시 장 개방화에 따른 글로벌 기업의 시장 참여, 동종 업계간 경쟁 심화, 소비자 욕구 변화의 가속화라는 새로운 시장상황에 어떻게 대처할 것인가라는 기업의 최대 현안을 해결하고자 하 는 방안으로 모색되었으며 기존의 불특정 다수 를 대상으로 하는 마케팅에서 탈피하여 목표고
객 개개인의 개성을 파악하고 그들의 수요를 충족시켜 상품이나 서비스에 대한 충성도를 높 이려고 하는 방법으로 개발되었다(산업기술연 구소 2000).

\section{2 백화점 채널에서 $\mathrm{CRM}$ 의 전략적 의미}

1990년대 후반 CRM이 본격적으로 국내에 소 개된 이후로 금융, 보헙, 제조업 등 여러 산업 에서 $\mathrm{CRM}$ 을 이용한 고객 관리 시도가 있어 왔다. 일반적으로 CRM 도입과 투자를 하기 위 해서는 구매주기와 상품단가가 일정 수준 이상 이어야 한다. 백화점에서 판매되는 화장품은 상 품 단가가 높고, 구매주기가 일정하기 때문에 이러한 기본 전제를 잘 충족시켜준다.

화장품 산업에서도 글로벌 브랜드와 태평양 등 백화점 채널에 진출한 브랜드들은 $\mathrm{CRM}$ 을 시도하거나 구축하고 있다. 그러나 글로벌 브랜 드들은 이미 강력한 브랜드 파워를 구축하였기 때문에 $\mathrm{CRM}$ 과 같은 고객전랴에 대한 필요성 을 상대적으로 덜 느끼고 있는 상황이었다. 그 에 비해 LG생활건강의 입장은 달랐다. LG생할 건강 화장품 사업부가 상대적으로 강세를 보인 중저가 전문점 시장이 급속히 축소되면서 백화 점 채널에서의 매출 확대는 절대 과제가 된 상 태였다. 게다가 브랜드나 백화점 유통 장악력이 약하기 때문에 $\mathrm{CRM}$ 을 통한 새로운 활로를 찾 아야 할 상황이었다.

\section{3 경쟁사의 $\mathrm{CRM}$ 현황}

고객접점에서 고객을 직접 상대하는 $\mathrm{CRM}$ 의 중요성이 날로 커져가는 것을 입증하듯 주요 
화장품 업체들도 $\mathrm{CRM}$ 의 비중을 높여가는 추 세다. 주요 업체들의 CRM 비중을 분석한 결과. 업체들은 평균 매출액의 $5 \%$ 정도를 $\mathrm{CRM}$ 을 위해 투자하고 있는 것으로 밝혀졌으며, 향후 그 비중을 높이겠다는 업체들이 대부분을 차지 했다. 일부 업체는 심지어 매출의 $40 \%$ 를 $\mathrm{CRM}$ 전개에 투자하고 있다고 밝혔다(CMN 2004). 〈표 3-1)과 같이 많은 기업들이 $\mathrm{CRM}$ 전담부 서를 설치하고 구체적인 활용을 하기 위해 노 력하고 있는 것으로 나타났다.

대부분의 회사들은 $\mathrm{CRM}$ 주요 담당 부서를 마케팅부 내에 고객만족팀 또는 고객상담실 등 의 이름으로 설치해 운영하고 있으며 일부 업 체는 별도의 독립 부서를 운영하고 있다. 이는 $\mathrm{CRM}$ 이 마케팅 기법의 하나로 중요성이 더해
져 가고 있기 때문인 것으로 분석되었다. 특히 일부 업체는 각 브랜드별로 고객상담팀이나 담 당을 배정해 운영할 정도로 CRM에 많은 비중 을 두고 있다(CMN 2003).

설화수와 헤라 브랜드를 보유한 태평양은 과 거 TFT 체제에서 최근 현업부서로 CRM업무 를 이관했고 정보 부문이 이를 지원하고 있었 다. 태평양은 $\mathrm{CRM}$ 의 기본 정책 수립 후 수행 계획을 상세화하고 필요한 정보시스템을 구축 해서 마케팅에 적용하고 있다.

코리아나 화장품은 별도의 CS(customer satisfaction; 고객 만족)센터를 운영하고 있다. CS 센터는 전국적인 서비스망을 구축하고 방문고 객에게 컴퓨터 스킨 체크 시스템을 이용해서 피부 관리 서비스를 제공하고 있었다. 또한 고

〈표 3-1〉 경쟁사의 CRM 현황 분석

\begin{tabular}{|c|c|c|}
\hline 회사 & 담당부서 & 특징 및 전략 \\
\hline 태평양 & $\begin{array}{l}\text { 해당현업부서별 } \\
\text { 담당정보부문 지원 }\end{array}$ & $\begin{array}{l}\text { 1. } \mathrm{RFM} \text { 을 통한 고객 분류 및 Event 관리 } \\
\text { 2. } \mathrm{DB} \text { 마케팅, } \mathrm{TM}, \mathrm{DM} \text { 을 통해 최적화된 } \mathrm{CRM} \text { 구현 } \\
\text { 3. } \mathrm{CRM} \text { 을 바탕으로 고객 카운슬링 강화 }\end{array}$ \\
\hline 코리아나 & CS센터 & $\begin{array}{l}\text { 1. Call Center 중심 CRM 전랴 } \\
\text { 2. CS센터운영, VIP 관리, } \mathrm{DB} \text { 마케팅, } \mathrm{DM} \text { 발송 }\end{array}$ \\
\hline 한국화장품 & 마케팅부서 $\mathrm{BM}$ & $\begin{array}{l}\text { 1. Partner Relationship Marketing 구축 및 } \mathrm{DB} \text { 마케팅 } \\
\text { 2. 평가단 모집 활동. 고객 모니터링제 활용 }\end{array}$ \\
\hline 니베아 & $\begin{array}{c}\text { 마케팅부 내 소비자 } \\
\text { 상담실 }\end{array}$ & $\begin{array}{l}\text { 1. 고객상담센터 운영, 소비자불만 모니터 } \\
\text { 2. 서울대 피부과와 Company Advisory Doctor 서비스 }\end{array}$ \\
\hline 샤넬 & 마케팅팀 & $\begin{array}{l}\text { 1. 고객카드, 마일리지 프로그램 운영 } \\
\text { 2. DM 발송, Event 초대를 통한 고객 확대 } \\
\text { 3. 브랜드 충성도의 정기적인 측정 }\end{array}$ \\
\hline 로레알 & 마케팅팀 & $\begin{array}{l}\text { 1. 브랜드별 고객 Club제도 운영, 구매금액 적립 } \\
\text { 2. 구매금액에 따라 샘플 및 제품을 제공 }\end{array}$ \\
\hline 크리스천 디올 & 마케팅팀 & $\begin{array}{l}\text { 1. VIP 프로그램인 Prestige Club 프로그램 운영 } \\
\text { 2. 구매누적 금액에 따라 선물 및 사은품 제공 }\end{array}$ \\
\hline
\end{tabular}

자료: 각사 홍보팀, 마케팅팀, $\mathrm{CRM}$ 담당자 인터뷰 정리 
객만족 정보를 전산화, 통계화해서 연구, 개발. 상품 기획 등 유관부서가 공유하는 $\mathrm{VOC}$ (voice of customer; 고객의 소리) 시스템을 확립함으 로써 고객 불평의 처리와 사후관리를 강화해 고객만족을 구현하고 있다.

샤넬은 $\mathrm{CRM}$ 활동의 가장 큰 목적을 고객과 의 장기적인 '관계' 형성에 두고 있다. 샤넬의 질 높은 제품을 경험해 본 고객들을 계속해서 행사에 초대해 얼굴을 마주보고 샤넬의 문화를 느끼게 해서 고객 스스로 '샤넬'이라는 문화에 익숙해져 진정한 '매니아'가 되어 자발적으로 다시 매장을 방문하게 만드는 것이다. 샤넬은 고객카드를 작성한 고객이 구매하는 정도에 따 라 마일리지를 부여하고 있다. 또한, 구매실적 과 매장 또는 행사장에 얼마나 자주 방문하는 지 등 여러 요소를 기준으로 고객의 브랜드 충 성도를 측정하고 있다.

\section{IV. 오휘의 $\mathrm{CRM}$ 활동 및 문제점 분석}

\section{1 $\mathrm{CRM}$ 활동 분석}

1990년대 후반부터 고객 $\mathrm{DB}$ 구축과 $\mathrm{CRM}$ 을 수행해 온 오휘의 CRM 활동은 시기별로 크게 3 단계로 구분할 수 있다. 1단계에서는 CRM 열 풍이 업계에 불어 닥친 1990대 후반, 백화점 고 객들의 정보를 수집하여 $\mathrm{DB}$ 를 구축하였다. 오 휘는 수집된 정보를 이용해서 다양한 이벤트를 통해 고객에게 자사 제품 촉진활동을 실시하였 다. 2 단계에서는 수집된 고객 $\mathrm{DB}$ 를 활용해서 고객 세분화 작업과 고객 관리의 기준을 설정 하였다. 3 단계에서는 $\mathrm{DB}$ 를 충실히 해서 이를 영업 현장에 활용할 수 있도록 $\mathrm{CRM}$ 프로젝트 들을 자체적으로 수행하였다(〈그림 4-1〉 참고).

그러나 이러한 오휘의 3 단계 $\mathrm{CRM}$ 활동의 성 과는 그리 좋지 않았다. 특히, 세분화된 고객에

〈그림 4-1〉 오휘 브랜드의 시기별 CRM 활동

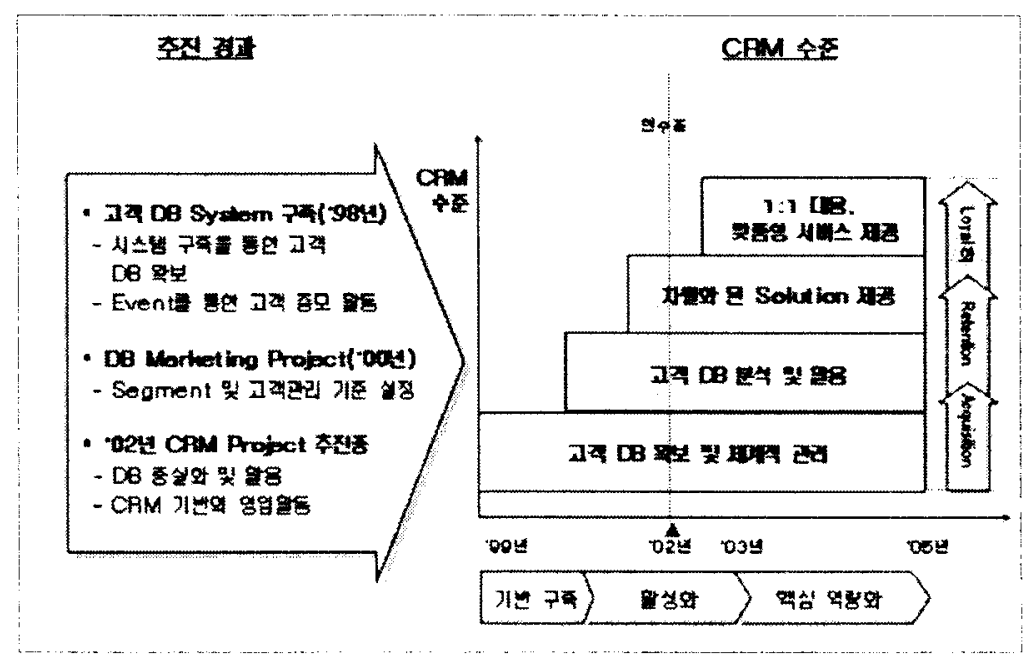


대한 차별화된 프로그램 운영이 충분치 않아서 브랜드 충성도가 글로벌 브랜드에 비해서 낮은 것으로 나타났다. 특히 충성고객대비 휴면고객 의 비율이 매우 높은 것으로 나타났다(<그림 4-3) 참고). 또한 백화점 고객 트렌드에 적합한 신규고객 확보로 시장점유율은 (그림 4-2)에서 보는 바와 같이 2000년 4.2\%에서 2001년 4.3\%, 2002 년 $4.7 \%$ 로 점진적으로 확대되어 가고 있으 나 선두 브랜드가 되기 위한 충분한 고객을 아 직 확보하지 못하고 있는 상황이었다. 업계 1 위 인 태평양의 2002년 백화점 고객이 약 50 만 명
인 것을 고려해 볼 때, 오휘는 이에 절반에도 미치지 못하는 수준이었다.

\section{2 고객 수익성 분석}

그런데 오휘 관계자들이 더욱 우려한 문제는 고객의 수나 시장점유율과 같은 양적인 성과가 아니라. 고객 수익성과 같은 질적인 측면에서 오휘의 경쟁력이 낮다는 것이었다.

고객들의 구매 기록을 조사한 결과, 기존고객 중 $56.5 \%$ 가 구매를 하지 않는 상황이며 꾸준한

〈그림 4-2〉 고객 확보 추이 및 매출 성과

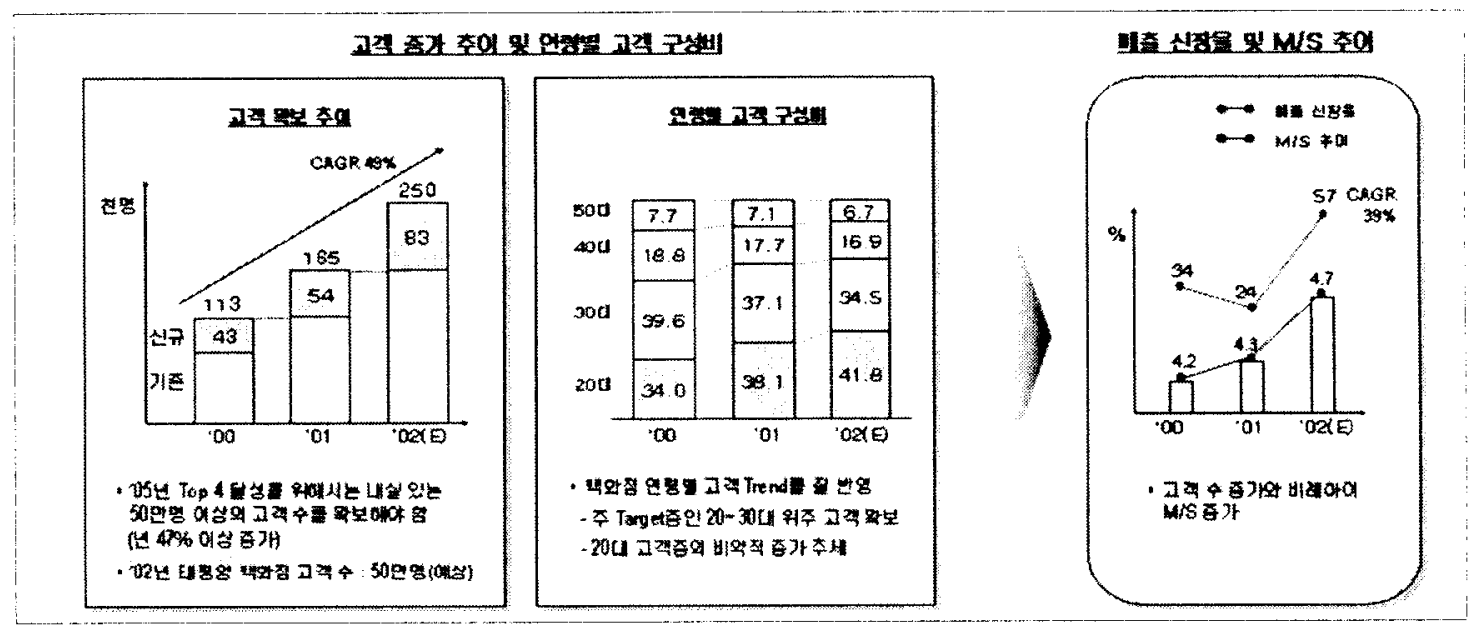

〈그림 4-3〉 기존고객의 휴면화 및 충성화 현황
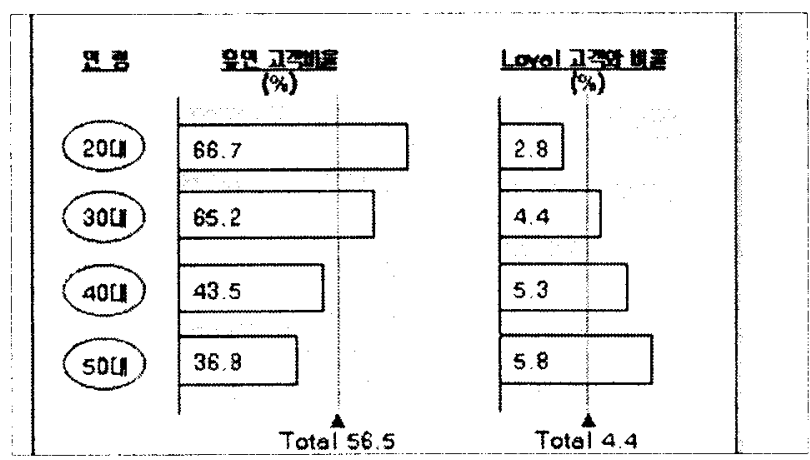
구매를 보이는 충성고객의 비율이 $4.4 \%$ 에 불과 했다. 더욱 큰 문제는 브랜드 목표 고객인 20 30 대 고객의 휴면 비율이 높은 반면, 충성고객 은 상대적으로 적은 것으로 나타났다는 것이다 (〈그림 4-3〉 참고). 따라서 획기적인 성과 개선 을 통한 이익 달성을 위해서는 다양한 마케팅 할동을 통해 휴면고객을 충성고객으로 유도하 는 방법이 필요한 상황이었다.

특히 〈그림 4-4)의 분석 결과에 나타난 것과 같이 활성고객 및 충성고객의 1 인당 연간 구매 액이 신규고객에 비해 1.5 배에서 5 배 이상까지 많게 나타났다. 이 결과를 보고 오휘 관계자들
은 안정적인 수익 기반을 확보하기 위해서는 기존의 활성고객과 충성고객에 대한 양질의 고 객 관계 구축이 절실하다는 것을 깨달았다.

\section{3 고객 이탈 과정 분석}

한편, 지금까지 상당한 고객 확보 및 유지 노 력에도 불구하고 고객 휴면과 이탈 현상이 개 선되지 않았다고 판단한 오휘 브랜드 팀은 이 탈 원인을 찾기 위한 분석을 시작하였다.

이를 위해 고객들의 구매 이력을 분석하였다. 고객 이탈 과정에 대한 분석 결과 〈그림 4-5)

〈그림 4-4〉 인당 년 구매액 비교

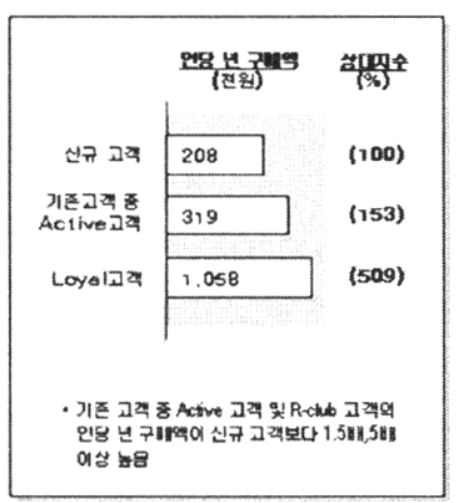

〈그림 4-5〉 구매 횟수 및 이탈 과정 분석

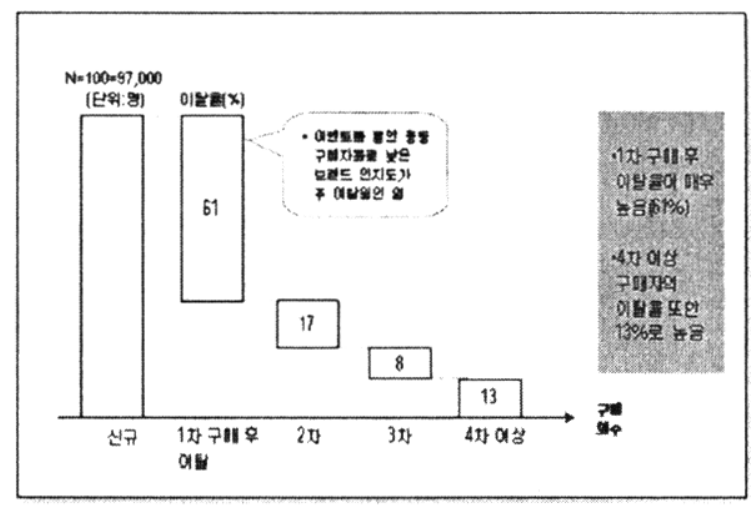


에서 보는 바와 같이 오휘를 1차로 구입한 후 재구매를 하지 않는 신규고객이 $61 \%$ 를 차지하 고 있다는 것을 발견하였다. 이는 브랜드에 대 한 선호도가 낮고 Event 행사를 통한 충동 구 매자들이 오휘 브랜드의 신규고객으로 가입되 는 경우가 많다는 것을 의미했다.

이와 같은 고객이탈 과정 분석을 통해 2차 구 매 전환 고객의 경우에는 충성화 가능성이 큰 것으로 나타났으므로 기존고객의 활성화와 충 성화를 높이기 위해서 신규고객의 2차 구매 전 환 프로그램의 운영 등으로 휴면과 이탈을 사 전에 예방해야 하며, 반복 구매자 중 충성고객 에 대한 차별적인 관리 프로그램이 필요하다고 오휘 관계자들은 잠정적인 결론을 내렸다.

\section{4 오휘 브랜드의 $\mathrm{CRM}$ 전략의 문제점 요약}

이와 같이 신규고객 확보 미흡, 충성도 제고 의 실패, 고객 흄면과 이탈의 근본적인 문제는 오휘 브랜드가 고객들에게 뚜렷한 가치를 제공 하지 못하는 데서 발생했다고 오휘 관계자들은 결론을 내리게 되었다. 오휘 브랜드 팀은 소비 자 분석 자료 및 고객 $\mathrm{DB}$, 경쟁사 벤치마킹 등 을 통한 종합적인 분석을 통해 이와 같이 오휘 브랜드가 어려움에 처한 원인을 구체적으로 분 석해 보았다. 그 결과 4 가지의 원인을 도출할 수 있었다.

첫째, 오휘 브랜드는 고품질의 기초화장품(화 장품은 크게 기초화장품과 색조화장품으로 나 누어진다)이 주류를 이루고 있다. 그러나 경쟁 사에 비해 오휘의 장점을 부각시킬 수 있는 과 학적이고 전문성 있으며 고급스러운 이미지를
제공할 수 있는 서비스 활동이 미흡하다는 것 을 밝혀냈다.

둘째, 확보한 고객정보를 적절히 활용하지 못 하고 있다는 점을 파악하였다. 특히 고객의 욕 구를 적극적으로 파악하기 보다는 기존고객이 인지하고 있는 제품을 소극적으로 권유하고 판 매하는 상황이었다. 이에 따라 기존고객에 대한 판매에 한계를 느끼게 되어 신규고객 확보에 더욱 치중하게 되었다. 그러나 약한 브랜드 파 워로 인해 신규고객 확보도 여의치 못해 악순 환을 반복하게 되었다.

셋째, 충성도 프로그램의 폭과 깊이의 문제였 다. 글로벌 브랜드는 매장 등 고객 접점에서 충 성고객에게 자긍심을 고취시킬 수 있는 다양한 VIP 초대 행사 등을 통해 차별적인 편익을 제 공하는 등 기능적 편익뿐만 아니라 심리적 편 익을 제공하였다. 그러나 오휘는 고객에게 구매 금액에 따른 보너스 포인트를 제공하는 등 판 매 유도 위주의 충성도 프로그램을 운영하였고, 구매고객에만 한정하여 Happy Call 및 문자 서 비스를 제공하는 등 단기적 매출 제고에 집중 했다는 문제점을 발견하였다.

마지막으로 고객관리 지원시스템의 문제가 있 었다. 경쟁사들은 고객 등급을 간단명료하게 정 리하여 영업현장에서 직원들이 호과적으로 활 용할 수 있게 만들었다. 이에 비해 오휘는 고객 등급의 수가 너무 많고, 이를 직원들이 쉽게 활 용하지 못하게 만듦으로써 본사의 전략과 마케 팅지원 시스템이 영업 현장에서 활용되지 못한 다는 것을 파악하였다.

$L G$ 생활건강 백화점 화장품 브랜트 오휘의 CRM전략 101 


\section{V. 오휘의 CRM 비전 수립}

이와 같이 오휘 관계자들은 오휘가 처한 부정 적인 상황과 그 원인을 파악하였다. 그리고 이 들 문제를 단기적이고, 단편적 관점에서 해결하 려 해서는 안 된다는 인식을 공유하게 되었다. 이를 위해 먼저 오휘가 추구하는 장기적인 $\mathrm{CRM}$ 비전을 설정하였다. 즉, 오휘와 관련된 구성원들이 왜 오휘에게 $\mathrm{CRM}$ 이 절실하며. 이 를 통해 궁극적으로 오휘가 고객들에게 전달하 고자 하는 가치를 공유하게 하였다.

이를 위해 먼저 $\mathrm{CRM}$ 비전을 만들었다. 즉, 양질의 $\mathrm{DB}$ 확보를 기반으로 하여 개별적이고 차별적인 고객관리 프로그램을 운영하여 고객 에게 감동을 주는 마케팅이라는 철학하에 백화 점 채널에서의 이상적인 고객관리의 전체상을 정립하고 다음과 같이 전략 방향과 단계를 정 하였다.

비전을 완성하기 위해 우선 20 30대 신규 목 표고객들을 충분히 확보해서 Critical Mass를 충족시키는 목표를 세웠다. 그리고 이들 신규고 객과 기존고객들의 구매 활성화를 유도하고, 충 성도를 제고시키기 위해 기존의 충성도 프로그 램을 총체적으로 혁신하기로 하였다. 이와 아울 러 고객의 욕구를 파악하여 차별적으로 가치를 제공하기 위해 고객 $\mathrm{DB}$ 를 업그레이드하고, 필 요한 정보들을 재정의하기로 하였다. 또한 과거 의 고객 등급이 과연 현실적으로 관리가 가능 한지를 점검하고, 만약 현실적으로 의미가 없다 면 고객 등급을 재정의하고, 기준을 구체화하는 작업을 하기로 하였다.

한편, 이와 같은 전랴적 차원의 작업을 마무
리 하고, 실제 매장. $\mathrm{DM}, \mathrm{TM}$, 온라인 등의 고 객 접점에 따라 고객들에게 차별적인 가치를 제공할 수 있는 역할을 설정하는 한편, 경쟁사 및 고객 조사를 바탕으로 고객 접점 특성에 맞 는 가치와 편익을 제공하는 실행 프로그램을 만들기로 하였다. 또한, 이러한 활동을 현장 직 원들이 고객을 응대하면서 효과적으로 활용할 수 있도록 IT 인프라를 구축하기로 하였다.

마지막으로 $\mathrm{CRM}$ 활동의 성과를 효과적으로 평가하고 관리할 수 있는 $\mathrm{KPI}$ (key performance index; 핵심성과지표)를 설정하고, 모니터링 할 수 있는 평가 시스템을 만들기로 하였다.

오휘 브랜드 팀은 이와 같이 뚜렷한 목표와 이를 달성하기 위한 전략. 그리고 세부 실행 프 로그램을 만들고, 이를 모니터링 할 수 있는 평 가 시스템을 만드는 일관된 프로세스를 구축하 기로 하였다.

\section{VI. 성과 제고를 위한 $\mathrm{CRM}$ 전략 과제의 실행}

\section{1 효율적 신규고객 확보}

오휘 브랜드 팀은 먼저 중장기 목표인 백화점 브랜드 'Top 4'에 진입하기 위한 첫 단계인 Critical Mass 수준의 고객을 확보하기 위한 세 부 전략을 수립하였다. 특히 오휘 브랜드의 목 표고객인 20 30대 신규고객을 확보하기 위한 노력을 집중하였다.

이를 위해 20 30대 고객 특성에 접근할 수 있는 네트워크와 접점을 발굴하였고 오휘 브랜 
드의 신규 구매율을 높일 수 있는 다양한 캠페 인 프로세스를 확립하였다.

과거 오휘는 백화점 카드를 보유한 소비자들 을 대상으로 $\mathrm{DM}$ 을 발송하거나, 매장을 방문한 고객들에게 시용품을 권하면서 첫 구매를 유도 하였다. 그 결과, 할인쿠폰이나 시용품으로 인 한 신규 고객유인율은 $13 \%$ 에 달하는 성과를 거두었으나, 2 차, 3 차의 반복구매가 유도되는 비율은 저조했다. 이를 해결하기 위해 무조건적 인 $\mathrm{DM}$ 발송이나 시용품 제공과 같은 무차별 마 케팅을 지양하고, 충성고객이 될 가능성이 높은 고객들을 선별하여 역랑을 집중하였다.

구체적인 실행 프로그램을 살펴보면, 〈표 6-1>에 나타난 것과 같이 고객 접점에 따라 목 표고객과 구체적인 활동 방향을 설정해서 실행 하고 있다. 특히, 과거와 달리 20 30대 목표고 객이 선호하는 의류와 신발 등과의 공동마케팅 을 강화하고, 온라인과 오프라인 마케팅을 결합 하여 신규고객 확보 노력을 극대화 하였다.

\section{2 충성고객 수 확대 및 충성도 제고}

이러한 활동을 통해 확보된 신규고객과 기존
고객을 충성고객화 하기 위한 전략을 수립하였 다. 충성도 제고를 위해서 오휘는 기존의 충성 도 및 고객관리 프로그램을 개선하였다.

이를 위해 구체적으로 오휘와 경쟁사들의 충 성도 프로그램을 비교하고 분석하였다. 그 결 과. 오휘는 자사의 충성고객 선정기준이 불합리 하고, 포인트 제도가 무척 복잡하다는 것을 발 견하였다. 오휘의 충성도 선정 기준은 과거 2 년 간 총 구매액이 120 만 원 이상이었다. 이는 가 장 일반화된 충성도 평가기준인 RFM(recent. frequency, monetary)에서 최근 구매실적이 반 영되지 않고 있다는 문제가 있었다. 이 문제점 을 파악해서 최근 구매 실적을 충성고객 선정 에 반영하기로 하였다.

또한, 오휘 브랜드가 운영하고 있는 포인트 제도가 매우 복잡하고 다양해서 고객뿐만 아니 라 직원들도 이해하기 쉽지 않다는 문제를 개 선하였다. 보너스, 누적, 감사 등 다양한 포인트 제도가 통합되어 운영되지 못해서 실제 고객들 이 이를 사용하기 어려웠다. 이를 해결하기 위 해 통합 보너스 포인트 제도를 운영하기로 결 정하였다. 그리고 고객들이 실제적으로 포인트 를 활용할 수 있도록 포인트 점수 금액 범위에

〈표 6-1〉 효율적 신규고객 확보를 위한 중점 활동

\begin{tabular}{|l|l|}
\hline \multicolumn{1}{|c|}{ 고객 접점 } & \multicolumn{1}{c|}{ 활동 방향 } \\
\hline 매이컵쇼. 정기 세일 & Seasonal Event 활성화 \\
\hline 백화점 $\mathrm{DB}$ 및 온라인 쇼핑몰 & $\begin{array}{l}\text { 3대 백화점 CRM 팀과 헙조 } \\
\text { 고객의 구매패턴 정보 획득 및 목표 고객 정교화 }\end{array}$ \\
\hline 점내 시용품 제공 & 캠페인 전용 샘플 개발 및 샘플 비치함 운영 \\
\hline 공동마케팅 & 문화센터 및 패션/의류 업체 \\
\hline $\begin{array}{l}\text { 오휘 사이트 및 } \\
\text { 뷰티아이 }\end{array}$ & $\begin{array}{l}\text { 백화점 판매기간에 온 / 오프 공동 이벤트 개최 } \\
\text { 구매유인을 위한 DM / 샘플 발송 }\end{array}$ \\
\hline
\end{tabular}


서 구매 가능한 신제품을 고객들에게 $\mathrm{DM}$ 을 통 해 알리는 활동을 추가하였다.

한편, 잠재적 유망충성고객을 충성고객으로 전환시키는 역량을 강화하였다. 지금까지는 매 장에서 충성고객에 대한 배려만 있을 뿐 유망 충성고객에 대한 관리가 부족하였다. 이를 해결 하기 위해 최초 구매에서 충성고객이 되기까지 단계별로 고객관리 활동을 강화하였다. 특히 2 차 구매고객에 대한 매력적인 감사선물을 제공 하며. 최초구매 시점에서 2차 구매 시 누릴 수 있는 고객 혜택을 소개하는 등의 중점개선 할 동을 하였다.

마지막으로 본사차원의 고객지원 프로그램을 강화하였다. 경쟁사들은 최우수 고객을 위한 패 션, 여행 등 생활 전반 서비스를 제공하는 VIP 전용 서비스 센터를 운영하거나. VIP 고객만을 위한 문화 및 미용강좌를 개설하고 있다. 그에 비해 오휘는 고객기념일 관리, 오휘지 발송 이 외에는 특별한 프로그램이 없었다. 또한 최우수 고객을 대상으로 하는 다양한 테마의 이벤트 행사 초대 활동이 부족하고, 고객 커뮤니티를
강화하는 활동도 미흡한 상태였다. 이를 개선하 기 위해 최우수 고객의 자긍심 고취를 위한 초 청행사를 강화하고 기념일 선물선택 제도를 도 입하였다. 또한 미용정보가 수록된 브랜드 소식 지인 오휘지를 고급화하고 샘플을 동봉하는 등 의 활동을 추가하였다.

\section{3 합리적인 고객 등급화}

충성도 프로그램의 정비와 아울러 고객 등급 에 대한 기준도 바꾸었다. 지금까지 오휘는 고 객 등급을 8 개로 나누어서 관리를 하였다. 그러 4 실제 백화점 매장에서는 이를 활용하는 것 이 쉽지 않았다. 등급이 너무 많고, 구별이 쉽 지 않아서 현실적으로 적절히 관리하고 응대하 기 어렵다는 것이 영업사원들이 공통적인 불만 이었다. 이 문제를 해결하기 위해 현장의 고객 관리 활동과 연계하는 방향으로 고객을 다시 등급화 하였다. 이에 따라 등급 별로 평가와 관 리가 용이하도록 5 개 등급으로 단순화하는 대 신에 등급별로 관리 포인트를 구체화 하였다.

〈표 6-2〉 오휘의 개선된 고객 등급

\begin{tabular}{|c|c|c|c|c|}
\hline \multirow{2}{*}{ 군집 명 } & \multicolumn{3}{|c|}{ 기준 } & \multirow{2}{*}{ 관리 포인트 } \\
\hline & 주기 & 횟수 & 금액 & \\
\hline 신규 & 6개월 내 & 1회 & & 재구매 유도 \\
\hline 일반 & 6개월 내 & 2회 이상 & & $\begin{array}{l}\text { 브랜드이미지 제고 } \\
\text { 구매시점 / 횟수 관리 강화 }\end{array}$ \\
\hline 우수 & 6개월 내 & 4회 이상 & 1 년간 40 만 원 이상 & Up / Cross Selling \\
\hline $\begin{array}{l}\text { 최우수 } \\
\text { (R-Club) }\end{array}$ & $\begin{array}{l}\text { 6개월 내 } \\
\text { (신규가입 후 } \\
\text { 1년 이상 경과) }\end{array}$ & 4회 이상 & 1년간 60 만 원 이상 & $\begin{array}{l}\text { 신규추천 유도 } \\
1 \text { 대1 대응 }\end{array}$ \\
\hline 휴면 & 6개월 이상 & 1회 이상 & & 고객 활성화 \\
\hline
\end{tabular}


신규고객에 대해서는 재구매를 유도하고, 일 반고객에 대해서는 브랜드 이미지의 제고에 힘 썼다. 우수고객에 대해서는 교차판매를 유도하 였고, 최우수 고객들에게는 다른 고객들에 대한 구전을 유도하도록 만들었다.

\section{4 고객 정보의 충실화}

오휘가 경쟁사와 차별화되고 고객들의 욕구에 부응하는 매장 서비스와 가치를 제공하기 위해 서는 고객에 대한 다양한 정보가 필요했다. 오 휘는 1998년부터 고객 정보를 모으는 작업을
했지만 실제 이를 효과적으로 마케팅 활동에 활용하지 못했다. 가장 큰 원인은 마케팅 활동 에 필오한 정보들이 충실하지 못했기 때문이다. 그래서 오휘는 $\mathrm{CRM}$ 및 충성도 제고 프로그램 을 만들고 효과적으로 수행하기 위해 고객 정 보를 충실히 하는 작업을 진행하였다. 오휘의 데이터 수집의 가장 큰 특징은 〈표 6-3〉에서 볼 수 있듯이 주요 활용 목적을 고려하여 고객 으로부터 필수적으로 확보해야 할 정보를 정의 하고, 현재 확보된 정보를 파악한 후 추가로 확 보할 정보와 확보방법(판매원, 온라인 이벤트, 구매내역)을 파악하는 등의 구체적인 실행 방

〈표 6-3〉 LG생활건강의 DB충실화

\begin{tabular}{|c|c|c|c|c|c|c|c|}
\hline 활용 목적 & & 필요 정보 & & & & 보 방법 & \\
\hline \multirow{7}{*}{$\begin{array}{l}\text { 매장고객 } \\
\text { 대응력 } \\
\text { 제고 }\end{array}$} & 정보유형 & 상세 Data 항목 & $\begin{array}{l}\text { 기존 } \\
\text { 확보 }\end{array}$ & $\begin{array}{l}\text { 신규 } \\
\text { 확보 }\end{array}$ & 판매원 & $\begin{array}{l}\text { 온라인 } \\
\text { 이벤트 }\end{array}$ & $\begin{array}{l}\text { 구매 } \\
\text { 내역 }\end{array}$ \\
\hline & 인적 정보 & 성명, 주민번호, 주소, 직업 & 0 & & $\mathrm{O}$ & $\mathrm{O}$ & \\
\hline & 피부, 미용정보 & 피부관심사. 피부타입 & $\triangle$ & $\mathrm{O}$ & $\mathrm{O}$ & 0 & \\
\hline & 구매이력정보 & $\begin{array}{l}\text { 최초 구매일, 최종 구매일, } \\
\text { 구매횟수평균 구매액, 방문 } \\
\text { 경과기간. 최근 방문매장, } \\
\text { 구매상세 정보, 선호제품, } \\
\text { 재 구매 예상제품 }\end{array}$ & $\mathrm{O}$ & & $\mathrm{O}$ & & $\mathrm{O}$ \\
\hline & 고객평가정보 & 고객상태, 고객등급 & $\triangle$ & $\mathrm{O}$ & $\mathrm{O}$ & & $\mathrm{O}$ \\
\hline & 캠페인정보 & 최근 캠페인정보, 반응정보. & $\triangle$ & $\mathrm{O}$ & & & 0 \\
\hline & 포인트정보 & 적립 포인트, 사용포인트 & $\mathrm{O}$ & & & & 0 \\
\hline \multirow{2}{*}{$\begin{array}{l}\text { 구매보상 } \\
\text { 방식개선 }\end{array}$} & 고객선호 정보 & 고객선호 사은품 & & $\mathrm{O}$ & $\mathrm{O}$ & $\mathrm{O}$ & \\
\hline & 라이프스타일 & 취미, 관심분야 & $\triangle$ & 0 & $\mathrm{O}$ & O & \\
\hline $\begin{array}{l}\text { 추가판매 } \\
\text { 기회마련 }\end{array}$ & 라이프 이벤트 & 생일, 결혼기념일. 기타 & $\triangle$ & $\mathrm{O}$ & 0 & $\mathrm{O}$ & \\
\hline $\begin{array}{l}\text { 신규고객 } \\
\text { 확보 }\end{array}$ & 마케팅 & $\begin{array}{l}\text { 방문계기 } \\
\text { (추천, 광고. 캠페인 등) }\end{array}$ & & $\mathrm{O}$ & $\mathrm{O}$ & $\mathrm{O}$ & \\
\hline
\end{tabular}

※ $\mathrm{O}$ : 확보된 정보 $\triangle$ : 확보진행중인 정보 
안을 만들었다는 것이다. 또한, 필요한 정보를 유형별로 나누고 각각의 정보유형에 대해 상세 하게 데이터 항목을 구체화하였다.

\section{5 고객 접점에서의 차별적인 관리}

한편, 오휘는 글로벌 브랜드뿐만 아니라 태평 양에 비해서도 입점해 있는 백화점의 지명도와 규모, 매장위치와 크기 면에서 전반적으로 열세 에 있었다. 이를 극복하기 위해 다양한 충성도 프로그램을 만들어서 고객들을 유인하는 것과 더불어 매장에서 고객에 대한 차별적인 응대와 서비스를 제공하는데 많은 노력을 기울였다.

즉, 고객맞이(매장분위기, 기본자세), 고객응 대 및 상담(청취능력, 서비스 화법), 판매능력 (제품지식, 연결판매능력), 사후관리(전화응대, 업무처리능력)의 4 가지 단계에 따라 차별적인 고객 서비스를 체계적으로 제공했다. 특히 각 단계별로 중점적으로 개선하고 관리해야 할 사 항들을 명확히 하고, 이를 매장 직원들에게 숙 지시켰다. 또한 정기적으로 이러한 활동을 잘 하는 매장의 사례를 발표하게 하여, 직원들이
공유하도록 만들었다. 오휘의 단계별 고객응대 력 전랴은 다음과 같다.

첫째, 고객맞이 측면예서는 고객의 시선과 시 용환경을 고려하여 제품을 진열하고, 매장을 제 품 시용이 용이한 환경으로 바꾸었다. 또한, 종 업원에게 미소, 눈 맞춤, 인사말, 표정 등 기본 태도에 관한 교육기회를 확대하여 제공하였다.

둘째, 고객응대 및 상담 측면에서는 제품 설 명에 치우친 방식을 개선하여 적극적인 경청 능력을 배양하고 설득력 있는 화법을 구사하게 하였다.

셋째, 매장에서 적극적으로 판매를 유도하기 위해 매장 직원의 판매 기법 및 교차판매 역량 을 강화시켰다. 이를 위해 매장 직원에 대해 고 객의 특성을 파악하는 능력과 제품에 대한 지 식을 습득하도록 인센티브제도를 실시하고, 교 육제도를 지원하였다.

마지막으로, 사후관리 측면에서 감사전화와 $\mathrm{DM}$ 을 적극적으로 활용하면서 고객혜택에 대 해 적극적으로 소개하고 있고, 고객의 클레임 을 본사 고객센터로 연결하여 즉각 처리하도록 하였다.

〈표 6-4〉 고객응대력 평가 조사 항목

\begin{tabular}{|l|l|}
\hline \multicolumn{1}{|c|}{ 조사 내용 } & \multicolumn{1}{c|}{ 조사 항목 } \\
\hline 고객맞이 & $\begin{array}{l}\text { 매장 분위기: 제품진열 상태 등 } \\
\text { 기본자세: 첫인상, 친절성 }\end{array}$ \\
\hline 고객 응대 및 상담 & $\begin{array}{l}\text { 청취 능력: 고객욕구 탐색 } \\
\text { 서비스화법 및 설득력 제고: 신뢰성, 반론극복 }\end{array}$ \\
\hline 판매능력 & $\begin{array}{l}\text { 제품지식: 전문성, 제품신뢰도 } \\
\text { 연결판매 능력: 상품추천. 미래 고객화 능력 }\end{array}$ \\
\hline 사후관리 & $\begin{array}{l}\text { 전화응대 } \\
\text { 업무처리 능력: 사후관리 체계 숙지, 클레임 대처 능력 }\end{array}$ \\
\hline
\end{tabular}




\section{6 고객 커뮤니케이션 효율화}

매장에서의 차별화된 서비스의 제공과 더불어 $\mathrm{DM}$ (direct mail), TM(telemarketing), 온라인 등의 커뮤니케이션의 활용 방법과 내용을 개선 하였다.

과거에는 구매고객들을 대상으로 세일 등의 행사 소개 등 한정된 고객에 한정된 목적으로 $\mathrm{DM}$ 을 사용하였다. 게다가 $\mathrm{DM}$ 의 발송의 주체 가 오휘가 아닌 LG생활건강으로 되어 있어 브 랜드와의 연계성도 낮았다. 이를 개선하기 위해 발송처에 오휘를 명기하였다. 그리고 미용정보 를 수록하고, 샘플동봉 등을 통해 고객들의 적 극적인 반응을 이끌어냈다.

둘째, TM은 충성고객을 대상으로 신제품 및 이벤트를 소개하고, 구매 제품에 대한 사용만족 도를 모니터링 하는데 활용하기로 하였다. 또한 고객의 특정 기념일에 Thank Call, Happy Call
등을 보내줌으로써 고객들과의 감성적 유대를 강화하였다.

셋째, 온라인을 통한 부가 서비스를 강화하였 다. 기존의 오휘 브랜드의 내용을 강화하고, 고 객들의 참여를 유도하기 위해 커뮤니터 개설 및 다양한 이벤트를 실시하였다. 또한 정기적인 인터넷 설문을 통해 고객들의 불만 요소를 파 악하도록 하였다.

\section{7 $\mathrm{CRM} \mathrm{KPI} \mathrm{선정} \mathrm{및} \mathrm{관리}$}

오휘의 CRM 사례가 다른 CRM 사례에 비해 가장 뚜렷한 차별성을 가지고 있는 것이 바로, 전략을 수립하는 과정에서 이를 평가할 수 있 는 $\mathrm{KPI}(\mathrm{key}$ performance index: 핵심 성과 지 표)를 매장단위까지 설정하고, 진행 상황을 분 기별로 모니터링 하고 있다는 점이다.

백화점 $\mathrm{CRM} \mathrm{KPI} \mathrm{및} \mathrm{목표에} \mathrm{관해서} \mathrm{살펴보}$

〈표 6-5〉 오휘의 CRM KPI 및 목표

\begin{tabular}{|c|c|c|c|}
\hline $\begin{array}{l}\text { 성과 } \\
\text { 구분 }\end{array}$ & 핵심 요인 & \multicolumn{2}{|c|}{ 평가지표 } \\
\hline \multirow{2}{*}{$\begin{array}{l}\text { 성과 } \\
\text { 지표 }\end{array}$} & 경영 목표 달성 & \multicolumn{2}{|l|}{$\begin{array}{l}\text { 매출액 } \\
\text { 경상이익 }\end{array}$} \\
\hline & 시장 지배력 & \multicolumn{2}{|l|}{ 시장점유율 } \\
\hline \multirow{3}{*}{$\begin{array}{l}\text { 전략 } \\
\text { 지표 }\end{array}$} & 고객 $\mathrm{DB}$ 확대 & \multicolumn{2}{|c|}{$\begin{array}{l}\text { 전체고객 수(천명) } \\
\text { 신규고개 수(천명) }\end{array}$} \\
\hline & 능동고객 수 증대 & \multicolumn{2}{|c|}{$\begin{array}{l}\text { 기존고객 중 능동고객 비율 }(\%) \\
2 \text { 차 구매 전환율 }(\%)\end{array}$} \\
\hline & 충성고개 관리 & \multicolumn{2}{|c|}{$\begin{array}{l}\text { R-club고객 수(천명) } \\
\text { R-club인당 년 구매액(천원) }\end{array}$} \\
\hline \multirow[t]{2}{*}{ 행동지표 } & \multirow{2}{*}{$\begin{array}{l}\text { 판매사원 고객응대 } \\
\text { 수준 질적 향상 }\end{array}$} & $\begin{array}{l}\text { 핵심정보입력율 } \\
\text { (능동고객 대상) }\end{array}$ & $\begin{array}{l}\text { 피부정보 } \\
\text { 라이프스타일 }\end{array}$ \\
\hline & & \multicolumn{2}{|c|}{ 고객응대력 평가 종합점수 } \\
\hline
\end{tabular}


면 성과를 경영목표달성(규모 및 성장성. 수익 성) 및 시장 지배력 향상과 관련된 '성과지표' 와 고객 $\mathrm{DB}$ 확대, 능동고객 수 증대, 충성고객 관리(충성고객 수 증대, 충성도 강화)와 관련된 '전략지표', 그리고 판매사원 고객 응대수준 질 적 향상 $(\mathrm{DB}$ 충실화 정도, 고객응대력 향상)과 관련된 '행동지표'로 구분하였다. 또한, 〈표 6-5>와 같이 각각의 지표에 대해 평가지표를 설정한 후 연도별 실적 목표를 구체적으로 정 립하였다.

특히 궁극적 목표인 재무성과 제고를 위한 대 고객 전랴지표를 설정하고, 이를 향상시킬 수 있는 행동지표를 설정하는 등 $\mathrm{CRM}$ 활동과 재 무성과를 연결시키는 CRM KPI 프로세스를 관 리함으로써 $\mathrm{CRM}$ 활동의 성공을 위한 조직과 구성원들의 동기부여를 유발시켰다.

$6.8 \mathrm{IT}$ 인프라 보강

마지막으로 $\mathrm{CRM}$ 활동예 대한 수준 향상과
실행력 제고를 위하여 IT 인프라를 확충하였다. 핵심업무를 고객관리, 매출 및 시장분석, 캠페 인관리, 사업관리로 분류하고 각각의 핵심업무 에 대해 필요한 정보를 습득하기 위한 IT 인프 라를 보강했다.

세부적인 정보를 습득하기 위해 OLAP 및 데이터 마이닝 시스템 구축과 $\mathrm{DB}$ 구조 및 항 목 개선과 같은 $\mathrm{DB}$ 분석 시스템의 구축을 선 행했으며 최적의 $\mathrm{DB}$ 분석 시스템 구축을 위한 프로세스 및 소프트웨어를 선정하였다.

또한 IT 인프라 보강 활동으로서 온-오프라 인 정보 연계 시스템을 구축하고 e-learning 및 인터넷 마케팅을 통해서 온-오프라인의 연계에 의한 시너지 효과를 강화하였다. 마지막으로 캠 페인 관리 시스템, 영업 스케줄링 및 모니터링 시스템 구축과 같은 영업지원 시스템인 $\mathrm{CAP}$ Level-up을 통해 IT 인프라를 보강하였다(〈그 림 6-1> 참고).

〈그림 6-1〉 IT Infra 보강 활동

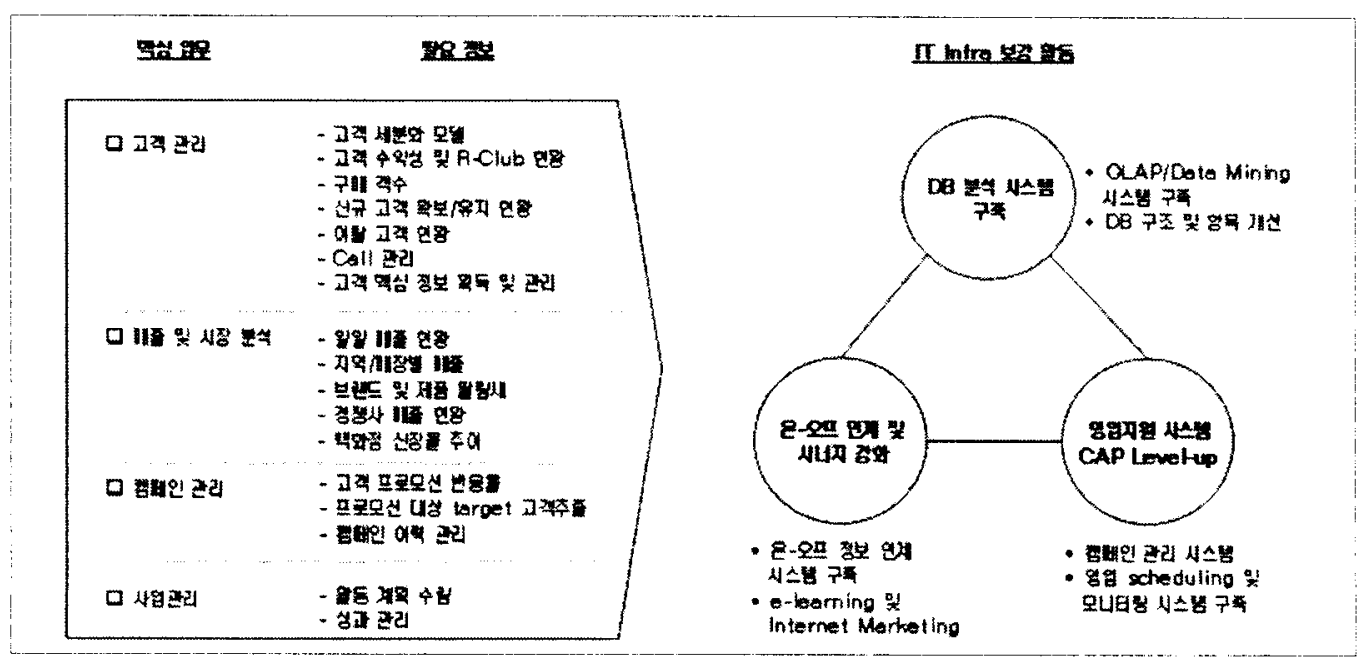




\section{VI. 오휘 $\mathrm{CRM}$ 활동의 성과}

이와 같은 체계적인 $\mathrm{CRM}$ 개선 활동에 힘입 어 오휘의 2003년 경영 실적은 상당히 개선되었 다. 백화점 부문 시장점유율이 2002년 $4.2 \%$ 에서 $4.7 \%$ 로 상승했고, 전년대비성장률도 $17.8 \%$ 로 백 화점 브랜드 중에서 2번째로 높았다(〈표 7-1) 참고). 점당 매출액도 6.98 억 원(2002)에서 7.95 억 원 $(2003)$ 으로 약 $13.9 \%$ 상승하였다. 이러한 성장률은 SKII 다음으로 높은 성장률이었다.

브랜드 선호도와 같은 태도적 고객만족도 역 시 70 점에서 85 점으로 증가하였다. 이와 같이 매출과 고객의 브랜드 선호도 모두 상승한 것 으로 나타나. 오휘의 $\mathrm{CRM}$ 활동은 성공적인 것 으로 나타났다. 특히 광고와 판촉비용이 전년대 비 증가율의 변화가 없었다는 점은 이러한 성 과의 객관성을 뒷받침해주고 있다.
VII. 시사점 및 미래에 대한 제언

\section{1 시사점}

지금까지 오휘 브랜드의 CRM 활동 사례를 살펴보았다. 오휘의 사례를 연구하면서 몇 가지 시사점을 얻을 수 있었다.

첫째. 오휘의 $\mathrm{CRM}$ 사례는 브랜드 파워가 약 한 기업이 $\mathrm{CRM}$ 활동을 통해 구체적으로 사업 성과를 개선할 수 있다는 것을 알려주고 있다. 즉, 충성, 유망고객을 대상으로 그들의 욕구에 맞는 가치와 편익을 제공할 경우 좋은 성과를 낼 수 있다는 것을 보여주고 있다.

둘째, $\mathrm{CRM}$ 전략과 실행 부서와의 유기적인 연결이 중요하다는 것을 시사해주고 있다. 오휘 도 처음에 충성도 프로그램을 만들거나 고객 등급을 정할 때 현장 직원들이 이를 실제적으

〈표 7-1〉 오휘의 브랜드 성과

\begin{tabular}{|c|c|c|c|c|c|c|}
\hline \multirow[b]{2}{*}{ 순위 } & \multirow[b]{2}{*}{ 브랜드 } & \multicolumn{3}{|c|}{ 2003년 } & \multicolumn{2}{|c|}{ 2002년 } \\
\hline & & $\begin{array}{l}\text { 매출액 } \\
\text { (억원) }\end{array}$ & $\begin{array}{l}\mathrm{M} / \mathrm{S} \\
(\%)\end{array}$ & $\begin{array}{c}\text { 전년대비성률 } \\
(\%) \\
\end{array}$ & $\begin{array}{l}\text { 매출액 } \\
\text { (억원) }\end{array}$ & $\begin{array}{l}\mathrm{M} / \mathrm{S} \\
(\%)\end{array}$ \\
\hline 1 & 설화수\&헤라 & 1.432 & 14.2 & 22.4 & 1,117 & 12.6 \\
\hline 2 & 에스티 로더 & 1,025 & 10.2 & 13.4 & 904 & 9.7 \\
\hline 3 & 랑콤 & 967 & 9.5 & 7.4 & 900 & 9.6 \\
\hline 4 & 샤넬 & 835 & 8.3 & -6.2 & 890 & 9.5 \\
\hline 5 & 크리스천 디올 & 616 & 6.1 & 1.0 & 610 & 6.6 \\
\hline 6 & 시슬리 & 601 & 6.0 & 5.4 & 570 & 6.1 \\
\hline 7 & 크리니크 & 490 & 4.9 & 8.2 & 453 & 4.9 \\
\hline 8 & 오휘 & 469 & 4.7 & 17.8 & 398 & 4.2 \\
\hline 9 & 시세이도 & 460 & 4.6 & 15.0 & 400 & 4.3 \\
\hline 10 & 비오템 & 326 & 3.2 & 3.2 & 316 & 3.4 \\
\hline
\end{tabular}

자료: 장업신문(2004.1) 
로 어떻게 활용하고 수행할지를 고려하지 않아 서 CRM 전랴을 만들고도 무용지물인 상태였 다. 이를 교훈 삼아 후에는 백화점 매장 직원, 온라인, 콜 센터 등 고객 접점에서 실제로 실행 할 수 있는 CRM 프로그램들을 만들어서 성공 하였다.

셋째. CRM은 살아있는 생명과 같이 항상 관 리해야 그 성과를 유지할 수 있다는 것을 시사 해 주고 있다. 지속적인 고객 정보의 업데이트 와 $\mathrm{CRM}$ 전략과 세부 활동의 보완과 변화만이 성공적인 $\mathrm{CRM}$ 을 담보해 준다는 것이다.

마지막으로, 이제 CRM 전락을 수립하고 실 행할 때도 각 수행 주체의 능동적인 참여와 수 행을 위해서 $\mathrm{KPI}$ 활동과 연계시키는 것이 바람 직하다는 것이다. 이와 더불어 $\mathrm{CRM}$ 시스템 활 동에 비용대비 효과를 고려하는 $\mathrm{ROI}$ 관점에서 $\mathrm{CRM}$ 을 관리해야 한다는 점도 시사해 주고 있다.

\section{2 미래에 대한 제언}

그러나 오휘 브랜드의 사례에서도 몇 가지 문 제점이 발견된다. 첫째, 고객등급화 과정에서 사용하는 변수가 소위 RFM 관련 변수로 제한 되어 있다는 것이다. 브랜드 선호도와 같은 태 도적 충성도를 반영하지 못하는 문제가 있다. 즉, 충성고객을 정의하는데 도식적으로 접근함 으로써, 충성고객의 특성을 파악할 수 있는 가 회를 줄였다는 점이다.

둘째, 오휘가 전략적으로 선택한 고객관리 프 로그램들의 상당 부분이 여러 기업의 성공 사 례를 참고한 점이다. 즉, 오휘만의 창의적 전략 이 부족하다는 것이다. 이 경우, 장기적으로 마 케팅 프로그램들이 내부 조직과의 적합성이 낮
아 문제를 발생시킬 가능성이 있다.

셋째, 오휘가 백화점에서 판매되는 고급 브랜 드임에도 불구하고, 고객들에게 가치를 제공하 는 방법이 주로 계산적(calculative) 편익에 치 중하여, 감성적으로 어필할 수 있는 감정적 (affective) 편익을 제공하지 못했다는 것이다. 기존의 많은 고객관계관리 이론에서 고객과의 강력하고 장기적인 관계를 유지하기 위해서는 감정적 편익을 제공하는 것이 중요한 것으로 밝혀져 있다(Verhoef et al. 2002; Morris et al. 1998). 그러나 아쉽게도 오휘의 충성도 제고 프로그램은 계산적 편익에 치우친 것들이 많았 다. 앞으로 이 부분의 개선이 필요하겠다.

마지막으로 최근 오휘의 성공 사례를 보고, 경쟁사 기업들도 $\mathrm{CRM}$ 활동의 개선을 통해 성 과제고를 모색하고 있다. 경쟁 기업들이 $\mathrm{CRM}$ 활동을 강화할 것으로 예상됨에 따라. 오휘 브 랜드는 자사의 CRM 활동을 차별화할 수 있는 전랴을 더욱 고민해야 할 상황이다. 과연 앞으 로 오휘의 대응 전략이 무엇일지에 관심을 가 지고 지켜볼 시점이다.

〈사례 접수일: 2004. 12. 03〉

〈게재 확정일: 2005. 02. 16〉

\section{참고문헌}

Cosmetic Marketing News(2003), "고객관리 첨 병 CRM 어디까지 왔나?," CMN, 2003.12.29. Cosmetic Marketing News(2004), "CRM 어떻 게 실천해야 하나?," CMN, 2004.1.4.

박성연(2003), “파워 브랜드 만들기, 전랴적 고 
객관계관리(CRM)의 부각," CMN. 2003.1.21. 산업기술연구소(2002), "고객 관계 관리의 현황

및 구축 방법." 산업기술연구소 논문집. 장업신문 $(2003)$, 최근 3 년간 최근 3 년간 유통경 로별 화장품 시장 규모와 점유비 추이, 2003.5.14.

장업신문 $(2003)$, 한국 화장품 유통별 브랜드, 장 업신문 2003.10.20.

장업신문(2003), 한국 화장품 유통별 브랜드 2, 장업신문 2003. 10.29.

장업신문(2004), 2003년 백화점 매출 실적, 장업

신문, 2004.1.28.

파이넨셜뉴스(2003), 브랜드 스토리: LG생활건

강 오휘, 파이넨설뉴스, 2003. 1.30.

한국경제신문(2003), 국산화장품 백화점서 “선전”,

한국경제신문 2003.4.

한국경제(2003), 뷰티 업계도 럭서리 마케팅 집

중, 한국경제신문, 2003.2.16.

Brown, Stanley A(2000), Customer Relationship

Management, John Wiley \& Sons.
Verhoef, Peter C.. Philip Hans Franses, Janny C. Hoekstra (2002), "The Effect of Relational Constructs on Customer Referrals and Number of Services Purchased From a Multiservice Provider: Does Age of Relationship Matter?", Journal of the Academy of Marketing Science, Volume 30. Number 3, 202-216.

Kumer. Nirmalya(2004), Marketing as Strategy, Harvard Business School Press.

Morris, Michael, Brunyee, Janinne and Page. Michael(1998) "Relationship Marketing in Practices," Industry Marketing Management, 10(Spring), 15-29.

Welch Jack and Byme John(2001). Jack: Straight from the Gut, IMG Literary.

www.cmn.co.kr

www.jangup.com

www.lgcare.com

www.ohui.co.kr 


\title{
LG Household and Healthcare' Cosmetic Brand, OHUI CRM Strategy Case
}

\author{
Wansoo Lee* \\ Wonmoo Hur**
}

\begin{abstract}
LG Household \& Healthcare has achieved its goals of revenue growth and customer loyalty increase by applying new CRM strategy of OHUI brand, which is ranked in the middle of department store cosmetic channel. OHUI has set up detailed CRM strategy in order to solve AS-Is issues found by systematical review. First. OHUI has gained critical mass and increased customer loyalty by developing customized loyalty program. OHUI also simplified customer types in order for employees to identify the customer type and apply the incentive program. As a result, the company has maximized the power of execution of its new strategy. Finally, OHUI has stabilized CRM by sharing best practice and implementing KPI. Throughout a series of CRM initiatives, OHUI has marked outstanding revenue growth and market share comparing to its competitors.
\end{abstract}

Keywords: Brand OHUI, CRM, customer relationship strategy, KPI

* Professor, School of Business. Yonsei University

** LG Economic Research Institute. Doctoral Candidate. School of Business, Yonsei University 